\title{
Textbook evaluation on Everyday English for Hospitality Professionals and English for Work in EFL Classroom
}

Sahyoni $^{1}$

${ }^{1}$ Corresponding author, English Teaching Department, State Islamic College (STAIN) Mandailing Natal, Indonesia; sahyoni.tb@gmail.com

\begin{abstract}
Textbook plays important role in teaching English. Yet, not all textbook is appropriately meet to the students' needs and knowledge level. The material for EFL is totally different to Native speaker of English. One of the ways matching students' needs and textbook is by doing textbook evaluation. This research is aimed at discussing textbooks that are used by the teacher in English Foreign Language (EFL). The textbooks that have been chosen are English for Everyday English for Hospitality Professionals by Lawrence, J. Zwier and Nigel Caplan (2007) and English for Work (2003) by Ian Badger. Both of them are ESP textbooks where they are taught in a foreign language class. The purpose of this research is to know how much Everyday English for Hospitality Professionals and English for Work textbook used in college meets the criteria of good EFL textbook. The research design is a descriptive-evaluative. The procedure of analyzing the data starts by analyzing the data based on EFL evaluation criteria, then finding out how much each items meet the criteria of good EFL textbook and concluding the result. The research result revealed that most parts of the textbooks are appropriately met to the students' needs. Most of the material stated inside of the textbooks covered students' knowledge level and relevant for field of study.
\end{abstract}

Keywords: evaluation, foreign learner class, textbooks

\section{Introduction}

The existence of textbook is not a new concept in the field of ELT. Textbook can be assumed as an old-existing media for teaching and learning activity. Textbook is kinds of important elements in education that always be valuable thing for every field of subject. It serves much valuable material for both teachers and students. It might be noted that the textbook becomes the essential source of knowledge, skill and experience. In teaching process textbooks are the ultimate weapon for a teacher in transferring knowledge to the students. The notions that can't be explained by teacher; but textbooks did it successfully. 
Since a long time ago, the textbook has been available for its usage to education field, every institution has textbook as a sources of myriad knowledge and countless information.

In line with the preceding statement, Immanuel (2010:5) viewed textbooks are the key part in most language programs. In some situations, they serve as the fundamental for many language inputs that learners receive and language practices that occur in the classroom. They may offer the basis for the content of the lessons, the balance of skills being taught, and the kinds of language practice the students take part. Materials should make students think critically and develop their knowledge gradually. They should also be resource books for ideas and instructional activities as well as giving teachers rationales for what they do. In addition, materials should be suitable for students' needs. Therefore, the textbooks being used in Indonesia specifically for English as a Foreign Language (EFL) in particular must go along with the EFL learners' needs. In EFL situation, students rarely have chances to use English outside the classroom, so English textbook seems to be the only source by which students receive input and the main material for both teachers and students to rely on as well (Park, 2004:2).

Moreover, in term of ideal concept, textbooks cover all students' needs and share various construction of insight. But, in fact some textbooks do not cover those criteria, only a few materials met with the students' need. Perhaps some of them had constructed perfectly and others hadn't. The question is arising on how the way to fix it? One of the possible answers is by doing evaluation and improvement. By all means, as lecturers we should have some judgment toward books that are being used in the classroom. In this paper, the researcher briefly evaluates the textbook, particularly English textbook for English Foreign Language. Those books are used by the collegian on campus. Both of them are functioned as ESP for them where English is not their mother tongue. The first book is English for tourism and secondly English for economic class.

\subsection{The role of textbook for teachers in English Language Teaching}

Needless to say, the textbook is an important material that can support the teachinglearning process in order to achieve the learning objectives. Pamungkas (2010:23) mentioned that a textbook was one of the many kinds of essential instructional materials used in learning and it was usually written, tightly organized, and greatly condensed. It indicates that, textbook and teaching instruction can't be separated partly. Both of them are correlated reciprocally and link one another. Teachers get knowledge from the book they then explain the materials in the book to the learner by their own ways. Raw materials are served by the books and the development materials are delivered by the lecturers.

However, textbooks must be used appropriately to achieve the objectives. There are some roles textbooks for teaching. Hutchinson and Torres in Awasthi (2006:1) affirms several roles, firstly, a textbook is an aid of teaching and learning. Textbook is an almost universal element of teaching and guidance for teachers, a memory aid for learners, and a permanent record for measuring what has been learnt during the class. Secondly, a textbook can also become the supplement for teachers' instruction in classroom. Thirdly, a textbook especially for inexperienced (novice) teachers or lecturers can provide ideas on kinds of materials and techniques. In broader idea, a textbook can be the guidance for teachers in giving the systematic materials for the students. It is generally noted that the role of the textbook is to be at the service of teachers and learners but not to be their master. 


\subsection{Textbook Evaluation}

Before moving to the further explanation, let review the nature of textbook definition. Textbook means a book that has detailed information about a course for people who are studying at that subject. It tells much information to the students, usually it constructed based on students' need and level. It means that a good textbook serves valuable information. Textbook is a source of knowledge for students much valuable information stated page by page by the author. It also links students and lecturers to enlarge their insight and expertise. Then, it moves to the definition of evaluation. The term evaluation means a process of giving judgment, calculation of quality, importance, value toward something. By that, it can be judged that textbook evaluation is a process of giving judgment toward material in the textbooks given to the learners. Textbook evaluation allows the reader (evaluator) to give their view of point, to put feedback on the material. This process needs a deep thinking and judgment by the evaluator.

Tomlinson (2011) defines textbook as a book which provides the core material. It covers a variety of issues for teaching-learning process within course period. Commonly, it consists of activities that related to four skills, grammatical and lexical information and various language functions. Conceptually Cunningsworth (1995) informs that there are three types of materials evaluation: Pre-use evaluation, in-use evaluation, and post-use evaluation. Preuse evaluation is when there is no actual experience of using the book for teachers to draw on. In-use evaluation refers to textbook evaluation whilst the materials are in use. Post-use evaluation provides retrospective assessment of a textbook's performance and can be useful for identifying strengths and weaknesses which emerge over a period of continuous use.

\subsection{Content Area of analysis}

In accordance with previous statements, content analysis is an analysis of the written or visual contents of a document. Besides, it is a research tool used to figure the presence of certain words or concept within texts or sets of texts. Babbie (1989) states that content analysis is the study of recorded human communications, such as books, websites, paintings, and laws. It is one of the methods used in analyzing qualitative data that looks at meanings and relationship such as words and concepts within various forms of data. This method can be applied to the existing material or new data and educational research as well.

\subsection{Criteria for Analyzing and Evaluating Content-Area Textbooks}

There are several criteria for evaluating the textbook as shown in the following table:

Table. 1. Criteria of textbooks evaluation

\begin{tabular}{|l|l|l|}
\hline No & Criteria & Explanation \\
\hline 1 & Objective of textbook & $\begin{array}{l}\text { 1. The aims of the textbook correspond closely with } \\
\text { the aims of teaching program/curriculum } \\
\text { 2. The materials objectives are apparent to both the } \\
\text { teachers and students. } \\
\text { 3. The objectives are systematically organized. }\end{array}$ \\
\hline
\end{tabular}




\begin{tabular}{|c|c|c|}
\hline & & $\begin{array}{l}\text { 4. The textbooks allow different teaching and learning } \\
\text { styles }\end{array}$ \\
\hline 2 & $\begin{array}{l}\text { Design } \\
\text { Organization }\end{array}$ & $\begin{array}{l}\text { 1. Do the pictures, graphs, and charts work well with } \\
\text { and support/extend the text itself? Do they vividly } \\
\text { illustrate the concepts covered? } \\
\text { 2. The textbook contain guidance about how the } \\
\text { textbook can be used. } \\
\text { 3. The textbook is accompanied with other teaching } \\
\text { learning materials (workbook, cassettes, and CD). } \\
\text { 4. There was review section and vocabulary list or } \\
\text { glossaries are included. } \\
\text { 5. Do the pictures, graphs, and charts work well with } \\
\text { and support/extend the text itself? Do they vividly } \\
\text { illustrate the concepts covered? } \\
\text { 6. Is the size of the print appropriate? }\end{array}$ \\
\hline 3 & Language skill & $\begin{array}{l}\text { 1. All language skills balanced and integrated } \\
\text { 2. Suitability of Listening skill learners } \\
\text { 3. Suitability of Speaking skill to learners. } \\
\text { 4. The reading passages are sufficient and suitable } \\
\text { with young learners' level ability. } \\
\text { 5. Writing activities are suitable with learner's level }\end{array}$ \\
\hline 4 & Language content & $\begin{array}{l}\text { 1. The language used in the textbook is authentic-i.e. } \\
\text { like real-life English. } \\
\text { 2. The Grammar items are appropriate to the learners. } \\
\text { 3. The vocabulary items are appropriate to the learners } \\
\text { 4. Do the illustrations and examples fairly represent } \\
\text { race, ethnicity, gender, and class? Are the } \\
\text { representations of people non-stereotypical? } \\
\text { 5. Are multiple and diverse perspectives offered in } \\
\text { relation to the content? } \\
6 \text {. Do the chapters contain opportunities for self- } \\
\text { assessment? Are there multiple formats for self- } \\
\text { assessment? } \\
\text { 7. All language skills (Reading, Writing, Listening, } \\
\text { Speaking) balanced and integrated within each unit. }\end{array}$ \\
\hline 5 & Topic & $\begin{array}{l}\text { 1. Are the topics of the textbook are relevant to the } \\
\text { learner's needs as English language learners? } \\
\text { 2. Are the topics of the textbook are interesting, } \\
\text { challenging and motivating? } \\
\text { 3. Is the topic sufficient enough for learner? }\end{array}$ \\
\hline 6 & Practical consideration & 1. Is the price of the textbook is reasonable. \\
\hline
\end{tabular}




\begin{tabular}{|l|l|l|}
\hline & $\begin{array}{l}2 . \quad \text { The textbook is recent publication and easily } \\
\text { accessible. } \\
3 . \quad \text { The book is strong and long-lasting. }\end{array}$ \\
\hline
\end{tabular}

\section{Method}

In this occasion, there are two textbooks that have been chosen by the writer. Firstly Everyday English for Hospitality Professionals by Lawrence, J. Zwier and Nigel Caplan. This book published on 2007 by Compass Publishing, it consist 7 chapters and 87 pages. This book serves material for health or medicine. Then, English for Work (2003) by Ian Badger published on 2003 and consisted of 91 pages.

This study was designed as descriptive-evaluative content analysis. Descriptive research is designed to obtain information concerning the current status of phenomena. In this research, the phenomenon was about the evaluation of English textbook which had been published by experts. This research was designed to evaluate textbook and describe the result of the evaluation.

The procedure of data analysis was as follows: (1) analyzing the data based on EFL evaluation criteria to find out how much each item of the checklist met the need of good EFL textbook criteria, (2) finding out how much each item of the checklist met the requirement of good EFL textbook criteria; and (3) concluding the result of the analysis.

\section{Finding and Discussion}

\subsection{Book I}

Before discussing further explanation, it is important for the writer to embark the classification of the book. This book is designed for nursing and doctor students.

\begin{tabular}{|c|l|}
\hline Title & :Everyday English for Hospitality Professionals \\
\hline Authors & :Lawrence, J. Zwier and Nigel Caplan. \\
\hline $\begin{array}{c}\text { Year of } \\
\text { Publishing }\end{array}$ & $: 2007$ \\
\hline $\begin{array}{c}\text { Place } \\
\text { Publishing }\end{array}$ & $:$ :Compass Publishing Inc \\
\hline Pages & $: 87$ pages \\
\hline ISBN & $:-8-15-599966-075-2$ \\
\hline
\end{tabular}

\subsubsection{Objective}

Textbook Everyday English for Hospitality Professionals is a textbook for nursing or doctor who studied health, hospitality and medical. In this opportunity, writer takes chapter VI which the topic is Helping Guests who are injured. Generally, the purposes of this book are:

1) To activate the reader "event schemata" their set of expectation about how ordinary hospitality even usually proceed

2) To concentrate on the most essential and most pictorial steps in activities 
3) To create pictorial association that aid in the storage and retrieval vocabulary knowledge.

In line with the aims of this book, it can be stated that the purpose of this book is relevant to the goal of hospitality curriculum. Hospitality needs learner to practice much than only achieving theory. In this book the authors serve several steps that simply can be done by the learner. It meets with the purpose of the curriculum which concentrate on the most essential and pictorial steps in activity. Then, the objectives of the books are constructed well chapter by chapter. It can be proved that, authors have arranged the objective based on the sufficient step from a simple one up to the complex one. However, this book does not allow the teacher to teach students in various techniques. It seems there are no various techniques for teaching. The students only learn through the pictorial series on it.

\subsubsection{Design and organization}

The pictures on this textbook look vividly and colorful which helps learner to learn the material easily. The colors are matching to the object and condition of hospital. It serves good impression for the reader and let students the real condition of hospital. One minor correction to be noted is the color of hair. The people's hair in this book is reddish and pink. Ideally, the color of their hair should be the black one since for Indonesian mostly have black hair. It is uncommon for Indonesian having such kinds of hair.

Furthermore, this book serves guidance how to use it appropriately. In the second page, authors clearly state how to use this book. The author wrote every chapter a list of vocabulary at the edge and bottom of the page. Each chapter in this book is about a process. The chapter can be studied in any sequence that makes sense for need the students. This book also completed with the CD for the learner. It allows the students to access not only hard copy but also soft one. In other hand, the weakness is no references or bibliography. Ideally, at the end of a book author states references or a bibliography as legal evidence where the authors get the material are.

\subsubsection{Language skill and content}

This book only discusses a skill for the learner. Some parts of this book cover vocabulary; possible skill used is the reading where the whole chapters serve pictorial series completed with a short explanation. Theoretically the book should put four integrative skills equally. As known, students also need to listen some terms that related as well as produces it in writing and speaking skill. This weaknesses lead the students only learn how to read not to write down a sentence or paragraph.

As an EFL student, nursing or doctor needs writing and speaking skill too. It could be assumed that the skills are imbalance portion. The language is suitable with student knowledge level and the grammar is in easy level. I could say, the language used in this book is properly acceptable for student language level. However, there is no assessment stated on this book. Indeed, assessment is much needed for the students to measure how far the progress of the students. Generally, there is none assessment for whole chapters. It strongly suggested that, authors must put assessment or exercise for the students in order to know students comprehension. In addition, the language is authentic for the learner, closely related with daily activity in hospital. It indicates the vocabularies used are matching with hospitality and health like: injured, patient, medical, description and many other vocabularies. 


\subsubsection{Topic}

As stated in the early explanation, the topic stated on this book is suitable for the learner. All the topics related with medical terms and hospitality. As in chapter VI, the topic is about helping a guest who injured. The authors completely state good chronological order and the solution how to cure or healing the patient professionally. The authors state the topic they then explain it by giving detail information how to treat the injury.

The topics have been arranged properly, for the first topic authors state topic about check in to the hospital, then healing some problem. At the end of the topic, authors appropriately state topic about check out. It means that learner must learn the material orderly, as illustration if the learners have not finished the first chapter yet, they can't move to the second chapter. The materials are illustrated well by giving pictorial series that are quite challenging and interesting for the learner. They might get the understanding easily the meaning by looking the picture and the list of vocabulary. Pictorial series also develops students' critical thinking and higher order thinking expertise.

\subsubsection{Practical Consideration}

Firstly, the price of this book is reasonable for the learner. Learner can get this book in the bookstore, that is, this book is availability in the certain place. Then, this book can be accessed in internet and this book is also available in soft copy. It allows students to access it easily if they can't find in the bookstore. This book also simple and thin consists of 87 pages long. This book is a recent publication where it was published in the recent year 2007. Authors also state that they always do evaluation year by year. This way is effective to update the new information and what the students' needs are. Authors try matching the material with the latest issues.

\subsection{Book II}

The classification of the book is presented as below:

\begin{tabular}{|c|l|}
\hline Tittle & : English for Work Everyday Business English \\
\hline Authors & : Ian Badger \\
\hline $\begin{array}{c}\text { Year } \\
\text { Publishing }\end{array}$ & $: 2003$ \\
\hline Publisher & : Longman \\
\hline Pages & $: 91$ pages \\
\hline
\end{tabular}

This book consists of 8 chapters. The writers take chapter 1 of this book. To carry out the evaluation, writer just analyzes the physical lay-out. The criteria can be showed as follow:

\subsubsection{Physical Layout}

Do the authors organize the material in a clear and meaningful manner? Give specific textual evidence to substantiate your description of the book's overall layout.

1. Are the chapters and subsections well organized? 
Author has sufficiently stated the objective of the book in the beginning of the chapter. Firstly, author introduces English for Work to the reader, continued with how the way to use this book, then it ends by stating the recommendation to the learner to choose the next series of this book. Unfortunately, author did not put the table on this book. Yet, the author states a picture for every chapter. The pictures are illustrated the concepts. Important to be noted that, the pictures didn't have a color, only two mixed color, black and white. I think, to illustrate vividly the concepts, the picture must be colorful. It also must match to the context. Author then put a talk-chart to every picture. I suppose this talk-charts are more interesting for the learner. Besides, it helps the reader to understanding the concept or meaning in the simple way. What I meant as a talk-chat presented as following:

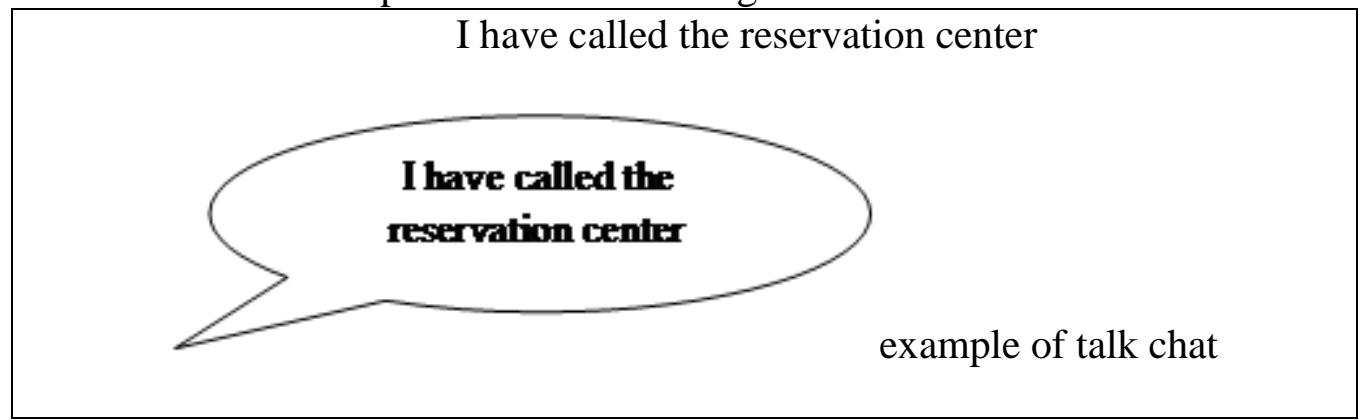

This book, I think special, due to every topic is presented in good order. Author state several phrases to guide students to do practice. It also served a glossary of vocabulary usage between British English and British UK. In another chapter, author gives a puzzle for boosting students understanding as well as a kind of challenging for them.

\section{Conclusion}

Based on those findings and discussion, it can be concluded that the textbook Everyday English for Hospitality Professionals was classified as adequately relevant to the EFL textbook evaluation criteria which could be seen from the level of suitability for the nursing or doctor. It means that teachers can use the textbook as a reference to teach the students of hospitality or nursing. Yet, it needs some revised version in order to complete the previous publishing. It is really recommended for lecturers to use this book as main book for teaching English specific purposes. The lecturers only need a minor revision on it.

There are some suggestions concerning the expected improvement of the textbook: (1) some writing activities should be modified and familiarized to students' levels; (2) the layout and pictures should be designed with natural color and its cover should contain more interesting photograph not a picture, because it can make students interested to the textbook and suitable with the students' culture. (3) It is also good for giving suggestion toward the four skills should be organized effectively; (4) the textbook should serve assessment for the learner. Then, the second book is nearly to a perfect construction where only a little mistakes on it. The lay out construction is very good. The author must give a colorful picture that suitable with the context and culture of the learner. The way how the author writes the table of content differs with commonly. It is truly suggested to make it as authentic as the author can. The book can be applied by the lecturers who teach nursery and hospitality subject. 


\section{References}

Awasthi, J.R. (2006).Textbook and Its Evaluation. (Online). Vol.11 No. 1-2. (www.nelta.org.np) accessed on February 3th, 2011

Babbie, E.(1989). Content Analysis, (Online), (http://en.wikipedia.org), retrieved on February 3th, 2009

Cunningsworth, A. (1995). Choosing Your Course book. Oxford: The Bath Press.

Immanuel. (2010). The Role of Material in a Language Classroom. Anti Essays. (http://www.antiessays.com/free-essays/65043.html) accessed on February 9th, 2012

Pamungkas, D. A.(2010). The quality of the English textbook used by International Standard Junior High school. Unpublished Thesis. English Department. Faculty of letters. State University of Malang

Park, E. (2004). A Study on English Textbook Used in a Technical High School: Issues in EFL. (Online), Vol.3 (http://TEFLIN.journal.ac.id) accessed on March 12th, 2011)

Tomlinson. B.(2011). Glossary basic for material development in language teaching and introduction, in Tomlinson (Ed) Material Development in Language Teaching. Cambridge: Cambridge university press. 